\title{
Redesigning the process of laparoscopic sleeve gastrectomy based on risk analysis resulted in 100 consecutive procedures without complications
}

\author{
Łukasz Kaska, Monika Proczko, Tomasz Stefaniak, Jarek Kobiela, Zbigniew Śledziński \\ Department of General, Endocrine and Transplant Surgery, Medical University of Gdansk, Gdansk, Poland
}

\begin{abstract}
Introduction: In recent years, laparoscopic sleeve gastrectomy (LSG) is becoming increasingly popular. The quite simple technique, lack of anastomoses, fully stapling course of the resection and the laparoscopic approach influence the attractiveness of the procedure from the surgeon's perspective. Though the feasibility of LSG is appreciated, the range of complications seems to be considerable.

Aim: To prospectively evaluate modification of the bariatric process in LSG patients.

Material and methods: The initial results of the first series of LSG patients (G1) were unacceptable and led to redefinition, based on risk analysis, of the entire bariatric process. A number of corrective and preventive actions were implemented into the process. The impact of innovations on the outcomes of the next 100 LSGs (G2) was assessed. Complications, intraoperative difficulties and postoperative adverse events were registered.

Results: The total complication rate of the G1 group was 32\% (8/25 patients). When several corrective and preventive actions were implemented in the subsequent process, there were no postoperative complications observed in the G2 group. Sixteen intraoperative difficulties were encountered in group $G 2$ but resolved intraoperatively and did not affect the postoperative course.

Conclusions: The systemic approach to the LSG procedure by innovating the entire process significantly reduced the rate of complications. The 'learning curve' should not be limited only to the manual operative training. Preventive actions based on risk analysis should be considered as the core component in redesigning the process.
\end{abstract}

Key words: laparoscopic sleeve gastrectomy, sleeve gastrectomy, bariatric surgery, complications, ISO, preventive actions.

\section{Introduction}

In the last decade, a distinct trend in the approach to restrictive procedures can be observed in bariatric surgery [1]. Laparoscopic sleeve gastrectomy (LSG) is currently displacing the previously dominant position of vertical banded gastroplasty (VBG), laparoscopic adjustable gastric banding (LAGB) or even proximal laparoscopic Roux-en-Y gastric bypass (LRYGB) [2, 3]. Since it has been observed that the impact on weight loss after LSG is surprisingly higher than it could result from restriction alone, the number of procedures is rapidly growing [4]. 
Sleeve gastrectomy initially constituted a firststep operation to achieve substantial weight loss prior to the more advanced malabsorptive surgery. It has been demonstrated [5-9] that this strategy reduces the risk of post-operative morbidity and mortality in over $50 \mathrm{~kg} / \mathrm{m}^{2}$ body mass index (BMI) individuals. Some of the patients after LSG quite unexpectedly show satisfactory weight loss without a second-step procedure and accept the mass gain, particularly when the resolution of obesity-associated morbidity is experienced [10]. Therefore the rate of complementary surgery seems to be much lower than primarily intended [11]. It could also be recognized as one of the reasons why LSG started to be performed as the sole procedure for individuals with varied $\mathrm{BMI}$.

The hormonal interference via limitation of ghrelin secretion following LSG intensifies the restrictive effect on metabolic improvement [12, 13]. Additionally, the value of the procedure is enhanced by its exceptional feasibility. The relatively simple operative technique, lack of anastomoses, fully stapling course of resection and laparoscopic approach make the operation attractive from the surgeon's point of view and encourage more frequent choice of this solution $[3,14]$.

However, the increasing popularity of LSG carries the concern of postoperative complications associated with the procedure, whose frequency is variable among the published data [15]. The mortality range is from $0 \%$ to $1.5 \%$ and the post-operative morbidity extends even above $20 \%$ after LSG [16]. Weiner et al. reported the higher surgical risk of LSG than LRYGB [3]

The most common LSG complications are: bleeding from the staple line, bleeding from the divided gastro-splenic or gastro-colonic ligament, leak, anatomical or functional stricture of the sleeve, intraabdominal abscess, bleeding to the digestive tract, splenic or hepatic injury, wound infection, trocar site hernia, pancreatitis, and pulmonary embolism [15].

It is generally known from the operators' opinions that the repeatable sequences of the operation do not always lead to desirable results and some of the adverse events' sources seem to be beyond the surgeon's control. Such independent factors cannot be improved only by surgical technical training but sometimes require changing the details in other parts of the process.

In the Department of General, Endocrine and Transplant Surgery of the Medical University of Gdansk, implementing the new procedure of LSG into the bariatric spectrum has been assessed as unacceptable. The high complication rate (32\%) led to suspension of bariatric activity and forced a redefinition of the entire process to improve patients' safety. The team focused on risk analysis, as the most important aspect of the planned change, targeted at the reduction of complications. The effectiveness of the modifications of the LSG strategy has been demonstrated in the study.

\section{Aim}

The aim of the study was to assess the impact of implemented innovations in separate parts of the process of laparoscopic sleeve gastrectomy on postoperative morbidity.

\section{Material and methods}

The prospective study, evaluating the impact of the innovated (after the unsatisfactory postoperative course of the initial 25 cases - group G1) LSG process on the early postoperative outcomes, was started in September 2009 and finished after 100 procedures in September 2012.

The complications and other adverse events in the G1 group and the way of their treatment are shown in Table I.

The criteria for patients' eligibility for bariatric surgery were in accordance with the guidelines of the International Federation for the Surgery of Obesity and Metabolic Disorders [17].

Laparoscopic sleeve gastrectomy, as a bridge operation to further bariatric surgery, was planned for $48(\mathrm{G} 1$ - 9, G2 - 39) patients with BMl above $50 \mathrm{~kg} /$ $\mathrm{m}^{2}$ (range $51-72 \mathrm{~kg} / \mathrm{m}^{2}$ ). The indication for the definitive procedure, in 77 cases (G1 - 16, G2 - 61), was BMI between $35 \mathrm{~kg} / \mathrm{m}^{2}$ and $50 \mathrm{~kg} / \mathrm{m}^{2}$.

Patients with BMI $35-50 \mathrm{~kg} / \mathrm{m}^{2}$, with type 2 diabetes (T2DM), gastro-esophageal reflux (GER), sweet or binge eaters, and those previously inefficiently treated with restrictive methods, were persuaded to undergo gastric bypass.

In both groups, the preoperative period, after the initial qualification, included: adequate blood tests, chest X-ray, abdominal ultrasound, upper GI endoscopy, endocrine evaluation, and 3 months nutritional and psychological preparation. In group G2 patients were obligated to lose at least $10 \%$ of the body 
Table I. G1 complications and the way of their treatment

\begin{tabular}{|c|c|}
\hline Complication & Treatment \\
\hline Bleeding from staple line* & Reoperation at postop. day 1. Staple line oversewing \\
\hline Bleeding from the gastro-splenic ligament* & Reoperation at postop. day 1 . Additional clips \\
\hline Naso-gastric tube entrapment in the staple line & $\begin{array}{l}\text { Reoperation at postop. day } 1 \text {. Removing the tube under laparoscopy } \\
\text { control. Additional simple suture of the sleeve }\end{array}$ \\
\hline Sleeve stenosis & $\begin{array}{l}\text { Endoscopic dilatation at postop. day 30. Reoperation (RYGB) } 6 \text { months } \\
\text { later }\end{array}$ \\
\hline Intra-abdominal bleeding* & $\begin{array}{l}\text { Continuing the drainage up to } 7^{\text {th }} \text { postoperative day. Transfusion } \\
\text { of } 2 \text { blood units }\end{array}$ \\
\hline Intra-abdominal bleeding* & Continuing the drainage up to $5^{\text {th }}$ postoperative day \\
\hline Intra-abdominal bleeding, hematoma, abscess* & $\begin{array}{l}\text { Continuing the drainage up to } 7^{\text {th }} \text { postoperative day. Antibiotic therapy } \\
30 \text { days }\end{array}$ \\
\hline Pancreatitis & Intensive conservative treatment \\
\hline $\begin{array}{l}\text { Aborted procedure due to restricted operative } \\
\text { area exposure (enlarged steatotic liver) }\end{array}$ & $\begin{array}{l}\text { Ultra-low-caloric diet (liver shrinking diet). Reoperation (LSG) } 3 \text { months } \\
\text { later after weight reduction }\end{array}$ \\
\hline $\begin{array}{l}\text { Aborted procedure due to restricted operative area } \\
\text { exposure (enlarged steatotic liver, abundant } \\
\text { intraabdominal fat) }\end{array}$ & $\begin{array}{l}\text { Endoscopic intra-gastric balloon for } 6 \text { months. Reoperation (LSG) } \\
8 \text { months later after weight reduction }\end{array}$ \\
\hline
\end{tabular}

weight during the preparation period. Additionally, G2 patients should keep on an ultra-low caloric (600 kcal) and low carbohydrate but rich in protein diet longer than in the G1 group (14 days vs. 7 days) before surgery to reduce the size of steatotic liver and gastrocolonic and gastro-splenic ligament fat.

Patients received prophylactic fractioned heparin for $12 \mathrm{~h}$ and one intravenous dose of antibiotic $30 \mathrm{~min}$ prior to the operation.

The last 100 LSGs have been performed by a fixed operative team (surgical and anaesthesiological). The accumulation of a few LSG procedures in one operative session and designating the operation room (OR) for bariatric surgery were provided in order to improve the process quality.

The LSG technique was standardized and depends on the purpose of the operation. When a definitive procedure was planned, the resection of the greater curvature was extended and the preparation of the gastro-colonic ligament started $2 \mathrm{~cm}$ from the pylorus and was continued to the angle of His close to the stomach edge. In super obese patients, the lesser sac was entered $6 \mathrm{~cm}$ from the pylorus to preserve part of the antrum.
In the $\mathrm{G} 2$ group, the $10 \mathrm{~mm}$ vessel sealing laparoscopic instrument was favored over the harmonic scalpel in skeletonizing the greater curvature, because of the larger coagulating surface of the jaws. The posterior stomach wall was liberated from the adhesions.

The number and sort of used linear-cutter device cartridges varied depending on the type of LSG.

For stapling the antrum in sole intentive LSG, one $60-\mathrm{mm}$ green reticulated cartridge $(4.8 \mathrm{~mm}$ staple height) of linear stapler was used in all patients. Regularly, 4-5 60- $\mathrm{mm}$ blue straight cartridges $(3.5 \mathrm{~mm}$ staple height) sufficed to complete the stomach resection in G2. Previously, in group G1, the first 2 cartridges were green.

In the bridge procedure in group $\mathrm{G} 2$, usually 4-5 $60-\mathrm{mm}$ blue cartridges were used for stapling the stomach. We stopped using higher staples (green) because of the sleeve margin bleeding observed in G1 patients.

Initially (G1), the sleeve was fashioned over a $30 \mathrm{~F}$ gastric tube but in subsequent cases (G2) the thicker $38 \mathrm{~F}$ bougie was used for calibration.

To provide the proper hemostasis, the border of the resection, in bleeding places, was clipped. Bleed- 
ing staple line over-sewing was not routinely done in $\mathrm{G} 1$ but was recommended in $\mathrm{G} 2$ patients. In the $\mathrm{G} 2$ group unidirectional thread 3.0 was used for reinforcement of the staple line.
The methylene blue test was obligatorily performed after removal of the calibration tube and clamping the pylorus.

Table II. Characteristics of G1 and G2 patients

\begin{tabular}{|c|c|c|c|}
\hline & G1 $\quad N=25$ & $N=100$ & $t$-Test \\
\hline \multicolumn{4}{|l|}{ Preoperative characteristics } \\
\hline Intention sole/bridge (ratio) & $16 / 9(1.8)$ & $61 / 39$ & NS \\
\hline Mean age (range) [years] & $42.4(22-64)$ & $44.2(19-65)$ & NS \\
\hline Male/female (ratio) & $8 / 17(0.47)$ & $33 / 67(0.49)$ & NS \\
\hline Mean BMI (range) [kg/m²] & $49.8(36-71)$ & $48.1(35-68)$ & NS \\
\hline Mean weight (range) [kg] & $144.8(98-189)$ & $147.5(97-180)$ & NS \\
\hline Diabetes & $3(12 \%)$ & $10(10 \%)$ & NS \\
\hline Hypertension & $18(72 \%)$ & $73(73 \%)$ & NS \\
\hline Sleep apnea & $7(28 \%)$ & $27(27 \%)$ & NS \\
\hline Degenerative joint disease & $10(40 \%)$ & $43(43 \%)$ & NS \\
\hline Dyslipidemia & $9(36 \%)$ & $38(38 \%)$ & NS \\
\hline Gastroesophageal reflux (GER) & $3(12 \%)$ & $11(11 \%)$ & NS \\
\hline Mean weight loss in preparation period [\%] & 3.4 & 11.8 & $p<0.05$ \\
\hline Mean duration of liver shrinking diet prior to LSG [day] & 5.4 & 14.4 & $p<0.05$ \\
\hline Previous intragastric balloon & $1(4 \%)$ & $3(3 \%)$ & NS \\
\hline Previous gastric banding & $1(4 \%)$ & $2(2 \%)$ & NS \\
\hline \multicolumn{4}{|l|}{ Intraoperative characteristics } \\
\hline Average operative time (range) [min] & $122(55-180)$ & $71(45-125)$ & $p<0.05$ \\
\hline Calibration tube [F] & 30 & 38 & \\
\hline Average blood loss (range) [ml] & $208(10-990)$ & $64(10-100)$ & $p<0.05$ \\
\hline Position & Anti-Trendelenburg & Semi-sitting & \\
\hline Reinforcement of staple line & Not routine & Recommended when bleeding & \\
\hline Hemostatic tool & Harmonic scalpel & Vessel sealing device & \\
\hline Fixed team & - & + & \\
\hline Designated OR & - & + & \\
\hline Cumulating the LSG procedures in series & - & + & \\
\hline Procedure abortion & $2(8 \%)$ & 0 & \\
\hline $\begin{array}{l}\text { Intraoperative difficulties with no impact } \\
\text { on postoperative outcome }\end{array}$ & Not registered & $16(16 \%)$ & \\
\hline Complications & 8 (32\%) & 0 & \\
\hline
\end{tabular}


A liquid diet was given for all patients for the first week, followed by soft protein-rich food for another 4 weeks.

Patients were followed up for 30 days after LSG to detect early unwanted effects of the operation. The visits were then continued 3, 6, 12 months and every year postoperatively to monitor the metabolic results of the treatment.

The characteristics of the patients of groups G1 and $\mathrm{G} 2$ are detailed in Table II.

\section{Management of complications and risk analysis}

The complications were managed based on the reputable quality management patterns established in points 8.5.2 (Corrective action) and 8.5.3 (Preventive action) of ISO 9001:2001 [18].

\section{Definitions}

Corrective action (CA) - activity undertaken after the analysis of a complication or other adverse event, addressed to the source of their occurrence, to prevent repeated onset.

Preventive action (PA) - activity undertaken as the result of risk analysis, addressed to the source of a potential complication or other adverse event, to prevent its manifestation.

The quality management system based on ISO 9001:2001 implemented in our institution required the following sequence of complications control: Each complication was reported, registered and examined during the routine clinical meetings. The most probable reasons were identified and the CAs were designed addressing the root causes of the problems. The solutions were implemented into the process map and became the routine clinical practice.

In parallel, the bariatric section analyzed the potentially intraoperative difficulties that could result in poor postoperative outcome. To minimize the complication rate some feasible PAs were suggested and adopted in the clinical procedure.

To compare groups t-tests were used. Statistical significance was considered for $p<0.05$.

The aim and the assumptions of the study were consistent with the requirements of the hospital quality management system ISO 9001:2001 and approved by the Authorized Representative of the Hospital Board.

\section{Results}

The analysis of the complications in the G1 group led to the identification of sources of adverse events and implementation of corrective and preventive actions in several parts of the entire process of LSG.

Bleeding and insufficient hemostatic care were recognized as the most common direct reasons for postoperative complications (5/8). In 4 cases, the surgeons did not reinforce the staple line with extra suturing but only clipped the bleeding vessels. In one case, identification of the bleeding source was unclear but one of the short gastric vessels was suspected. The investigation of these 5 cases revealed that operations were scheduled to be done in the first vacant $O R$ and all were performed late in the afternoon when the previous operations had finished.

One patient developed acute edematous pancreatitis as the result of irritation of the pancreatic body by too close harmonic scalpel activation, while releasing the adhesions of the posterior gastric wall. One patient was re-hospitalized because of distal part sleeve stenosis 30 days after a sole-intentive operation. During LSG, the tube had been calibrated with a $30 \mathrm{~F}$ bougie and additionally the staple line had been reinforced too tightly with the continues suture.

Finally, the calibration tube's entrapment in the mechanically sutured stomach wall was the direct reason for the reoperation of one patient. The poor cooperation with the anesthesiologist in correcting the bougie position was responsible for the error in this case.

In two cases, poor preoperative preparation of super obese and super-super obese patients led to bad exposure of the stomach because of the extremely large left lobe of the liver and abundant intra-abdominal fat, which resulted in untimely termination of the procedure.

A list of G1 complications and dedicated CA to prevent similar events is shown in Table III.

There were no postoperative complications observed in the subsequent consecutive 100 LSG cases.

In the G2 group, 16 (16\%) difficulties in 15 patients were experienced during the operative procedure, but intraoperatively managed did not influence the postoperative course. The direct reason for additional suturing in 10 patients was bleeding from the staple line uncontrolled by clips (in 6 of them the bleeding was observed 
Table III. Management of complications in G1

\begin{tabular}{|c|c|c|c|c|}
\hline $\begin{array}{l}\text { Complication/ } \\
\text { adverse event }\end{array}$ & Direct reason & Root cause & Corrective action & Result in G2 \\
\hline Aborted procedure & $\begin{array}{l}\text { Restricted operative } \\
\text { area exposure because } \\
\text { of enlarged steatotic } \\
\text { liver and abundant } \\
\text { intra-abdominal fat }\end{array}$ & $\begin{array}{l}\text { - Insufficient preoperative } \\
\text { preparation period } \\
\text { - Hasty qualification } \\
\text { - Inadequate supervision } \\
\text { of the qualification for } \\
\text { the LSG procedure }\end{array}$ & $\begin{array}{l}\text { - Tightening the requiremen- } \\
\text { ts of preoperative prepara- } \\
\text { tion period } \\
\text { - Mandatory weight reduc- } \\
\text { tion > } 10 \% \text { body weight. Liver } \\
\text { shrinking diet - } 14 \text { days } \\
\text { - The decision of qualifica- } \\
\text { tion for LSG procedure de- } \\
\text { pends on official bariatric } \\
\text { interdisciplinary team } \\
\text { position }\end{array}$ & $\begin{array}{l}\text { - No aborted procedures } \\
\text { - Reduction of average } \\
\text { operative time } \\
\text { - Prolonged preoperative } \\
\text { preparation period }\end{array}$ \\
\hline $\begin{array}{l}\text { Bleeding from } \\
\text { the staple line }\end{array}$ & $\begin{array}{l}\text { Inadequate hemostatic } \\
\text { efforts. } \\
\text { Resigning from over- } \\
\text { sewing when it } \\
\text { seemed to be effective }\end{array}$ & $\begin{array}{l}\text { - Late hours of the proce- } \\
\text { dures' performance } \\
\text { - Pressure on the opera- } \\
\text { tors to finish the proce- } \\
\text { dure by another OR team } \\
\text { - Randomly assigned OR } \\
\text { staff }\end{array}$ & $\begin{array}{l}\text { - Rescheduling the operation } \\
\text { list } \\
\text { - Designating separate OR } \\
\text { for bariatric service in spe- } \\
\text { cific terms } \\
\text { - Fixing and educating the } \\
\text { bariatric team }\end{array}$ & $\begin{array}{l}\text { - } \text { Reduction of intra- } \\
\text { operative blood loss } \\
\text { - No reoperations } \\
\text { - Increase of effective- } \\
\text { ness of OR service } \\
\text { - Reduction of average } \\
\text { operative time }\end{array}$ \\
\hline $\begin{array}{l}\text { Bleeding from the } \\
\text { gastro-splenic } \\
\text { ligament }\end{array}$ & $\begin{array}{l}\text { Inadequate hemostatic } \\
\text { efforts. } \\
\text { Bleeding not detected } \\
\text { during the procedure }\end{array}$ & $\begin{array}{l}\text { - Insufficient hemostatic } \\
\text { tools } \\
\text { - Inadequate inspection } \\
\text { of operative area }\end{array}$ & $\begin{array}{l}\text { - Harmonic scalpel repla- } \\
\text { ced by vessel sealing } \\
\text { device } \\
\text { - Inspection of operative } \\
\text { area with lower }(8 \mathrm{~mm} \mathrm{Hg}) \\
\text { intra-abdominal } \mathrm{CO}_{2} \\
\text { pressure }\end{array}$ & $\begin{array}{l}\text { - } \text { Reduction of intraope- } \\
\text { rative blood loss } \\
\text { - Randomly assigned } \\
\text { OR staff } \\
\text { - No reoperations }\end{array}$ \\
\hline $\begin{array}{l}\text { Calibration tube } \\
\text { entrapment }\end{array}$ & $\begin{array}{l}\text { Poor cooperation with } \\
\text { anesthesiologist }\end{array}$ & $\begin{array}{l}\text { - Randomly assigned OR } \\
\text { staff } \\
\text { - Engaged anesthesiolo- } \\
\text { gist not educated in ba- } \\
\text { riatric specificity }\end{array}$ & $\begin{array}{l}\text { - Fixing and educating the } \\
\text { bariatric team } \\
\text { - Improvement the coordina- } \\
\text { tion }\end{array}$ & $\begin{array}{l}\text { - No reoperations } \\
\text { - Reduction of average } \\
\text { operative time }\end{array}$ \\
\hline Pancreatitis & $\begin{array}{l}\text { Irritation of the pancre- } \\
\text { atic body by harmonic } \\
\text { scalpel activation } \\
\text { while releasing the } \\
\text { adhesions }\end{array}$ & $\begin{array}{l}\text { - Activation of the harmo } \\
\text { nic scalpel too close to } \\
\text { the pancreatic surface }\end{array}$ & $\begin{array}{l}\text { - Exercising particular cau- } \\
\text { tion in activating energy } \\
\text { emitting instruments } \\
\text { in pancreatic contiguity }\end{array}$ & $\begin{array}{l}\text { - No more pancreatitis } \\
\text { diagnosed }\end{array}$ \\
\hline Sleeve stenosis & $\begin{array}{l}\text { Too tight sleeve crea- } \\
\text { tion enhanced by } \\
\text { over-sewing }\end{array}$ & $\begin{array}{l}\text { - Too narrow calibration } \\
\text { tube }\end{array}$ & $\begin{array}{l}\text { - Change the calibration } \\
\text { tube }\end{array}$ & $\begin{array}{l}\text { - No more stenosis } \\
\text { observed } \\
\text { - Reduction of postope- } \\
\text { rative vomiting and } \\
\text { GER episodes }\end{array}$ \\
\hline
\end{tabular}

in the place where a green cartridge had been applied) and the margin of the resection had to be sutured.

In 3 cases, the hepatic injury caused by the nail of the trocar had to be supplied with a hemostatic sponge. These three patients, as they testified postoperatively, followed a liver shrinking diet shorter than required and an enlarged liver was observed during the operations.

One procedure was disrupted by a defect of the cartridge that stuck in the stomach tissue after being fired. It was cut out and the stomach wall was imme- 
Table IV. Preventive actions for G2 patients established as recommendations in the LSG process

\begin{tabular}{|c|c|c|c|}
\hline $\begin{array}{l}\text { Potential complication } \\
\text { or adverse event }\end{array}$ & Preventive action & & Area \\
\hline \multirow{4}{*}{$\begin{array}{l}\text { Aborted operation due to } \\
\text { abundant visceral fat and/ } \\
\text { or enlarged liver }\end{array}$} & Preoperative body weight reduction $>10 \%$ & 1 & \multirow{4}{*}{$\begin{array}{l}\text { Preoperative preparation program } \\
\text { supervision }\end{array}$} \\
\hline & Liver shrinking diet - 14 days & 2 & \\
\hline & Intra-gastric balloon when $\mathrm{BMI}>70 \mathrm{~kg} / \mathrm{m}^{2}$ & 3 & \\
\hline & Final qualification dependent on team position & 4 & \\
\hline \multirow{2}{*}{$\begin{array}{l}\text { Operation process } \\
\text { efficiency impairment }\end{array}$} & Cumulating the LSG procedures in designated OR & 5 & \multirow[t]{2}{*}{ Bariatric procedures scheduling } \\
\hline & Fixed bariatric OR team & 6 & \\
\hline \multirow{4}{*}{$\begin{array}{l}\text { Liver injury during trocar } \\
\text { insertion }\end{array}$} & Prolonged liver shrinking diet in super obese patients & 7 & Preoperative preparation program \\
\hline & Semi-sitting position & 8 & \multirow[t]{3}{*}{ Procedure initiation } \\
\hline & Insufflation by microlaparotomy & 9 & \\
\hline & $\begin{array}{l}\text { Insertion the trocars under vision control after } \\
\text { a full wall thickness notch (minimize the pushing } \\
\text { pressure at time of insertion) }\end{array}$ & 10 & \\
\hline \multirow{5}{*}{$\begin{array}{l}\text { Bleeding from the gastro- } \\
\text { colonic and gastro-splenic } \\
\text { ligament }\end{array}$} & $\begin{array}{l}\text { Application of advanced hemostatic tools with } \\
\text { maximal clamp size }\end{array}$ & 11 & Operative equipment selection \\
\hline & $\begin{array}{l}\text { Suspending calibration tube placement to preserve } \\
\text { flexibility of the stomach }\end{array}$ & 12 & \multirow[t]{3}{*}{ Greater curvature mobilization } \\
\hline & Activating the ligation close to the greater curvature & 13 & \\
\hline & Avoiding tension during ligation & 14 & \\
\hline & $\begin{array}{l}\text { Final inspection with abdominal } \mathrm{CO}_{2} \text { pressure } \\
\text { reduced to } 8 \mathrm{~mm} \mathrm{Hg}\end{array}$ & 15 & Final procedure control \\
\hline \multirow[t]{2}{*}{ Stapler failure } & $\begin{array}{l}\text { Examination of the device before use (close-open- } \\
\text { close) }\end{array}$ & 16 & \multirow[t]{2}{*}{ Supervision of the suppliers } \\
\hline & Reporting the adverse events to the producer & 17 & \\
\hline \multirow{4}{*}{$\begin{array}{l}\text { Uncompleted fundus } \\
\text { resection, segmental } \\
\text { dilatation }\end{array}$} & $\begin{array}{l}\text { Mobilizing the fundus by intensive release of } \\
\text { adhesions up to left crura }\end{array}$ & 18 & \multirow[t]{4}{*}{ Applying staplers } \\
\hline & $\begin{array}{l}\text { Careful release of adhesions of posterior gastric } \\
\text { wall up to lesser curvature vessels }\end{array}$ & 19 & \\
\hline & $\begin{array}{l}\text { Spreading the stomach before stapling by grasping } \\
\text { the greater curvature at site of short vessel stumps }\end{array}$ & 20 & \\
\hline & $\begin{array}{l}\text { Firing the staplers as close to the calibration tube as } \\
\text { possible }\end{array}$ & 21 & \\
\hline \multirow[t]{5}{*}{ Staple line leakage } & $\begin{array}{l}\text { Use of green cartridge when first is applied close to } \\
\text { the pylorus or last when banding was previous } \\
\text { procedure }\end{array}$ & 22 & \multirow[t]{3}{*}{ Applying staplers } \\
\hline & $\begin{array}{l}\text { Arranging the staplers in one line without angula- } \\
\text { tions between cartridges }\end{array}$ & 23 & \\
\hline & Firing the staplers without stomach tension & 24 & \\
\hline & $\begin{array}{l}\text { Over-sewing the uneven staple line with omentum } \\
\text { using unidirectional thread }\end{array}$ & 25 & \multirow[t]{2}{*}{ Staple line reinforcement } \\
\hline & $\begin{array}{l}\text { Additional suturing of the edge when intraoperative } \\
\text { leakage detected }\end{array}$ & 26 & \\
\hline
\end{tabular}


Table IV. Continued

\begin{tabular}{|c|c|c|c|}
\hline \multirow{2}{*}{$\begin{array}{l}\text { False negative result } \\
\text { of methylene blue test }\end{array}$} & Naso-gastric tube placement under vision control & 27 & \multirow[t]{2}{*}{ Final procedure control } \\
\hline & $\begin{array}{l}\text { Methylene blue test after pylorus clamping with } \\
\text { intra-sleeve pressure }>30 \mathrm{~mm} \mathrm{H}_{2} \mathrm{O}\end{array}$ & 28 & \\
\hline \multirow[t]{5}{*}{ Staple line bleeding } & $\begin{array}{l}\text { Dalteparin sodium } 5000 \text { IU s.c. } 12 \mathrm{~h} \text { instead } 1 \mathrm{~h} \\
\text { before surgery }\end{array}$ & 29 & Preoperative prophylactic \\
\hline & $\begin{array}{l}\text { Over-sewing the staple line when numerous sources } \\
\text { of intra-operative oozing or bleeding detected }\end{array}$ & 30 & \multirow[t]{3}{*}{ Staple line reinforcement } \\
\hline & Over-sewing staple line when green cartridges applied & 31 & \\
\hline & $\begin{array}{l}\text { Over-sewing the staple line when relatively thin } \\
\text { gastric wall observed }\end{array}$ & 32 & \\
\hline & Final inspection with reduced abdominal $\mathrm{CO}_{2}$ pressure & 33 & Final procedure control \\
\hline Trocar site bleeding & Trocar sites inspection & 34 & Final procedure control \\
\hline \multirow[t]{3}{*}{ Tube entrapment } & $\begin{array}{l}\text { Proper cooperation with anesthesiologists during } \\
\text { calibration tube manipulation }\end{array}$ & 35 & \multirow[t]{3}{*}{ Cooperation with anesthesiologists } \\
\hline & $\begin{array}{l}\text { Inserting the calibration tube under vision control } \\
\text { just before staplers application }\end{array}$ & 36 & \\
\hline & $\begin{array}{l}\text { Exposure of the tube position by palpating and } \\
\text { flattening the gastric wall with the tool }\end{array}$ & 37 & \\
\hline \multirow[t]{2}{*}{ Pancreatitis } & $\begin{array}{l}\text { Avoiding activation of energy emitting tools close } \\
\text { to the pancreatic surface }\end{array}$ & 38 & Posterior wall mobilization \\
\hline & $\begin{array}{l}\text { Instead of intensive release of adhesions close to the } \\
\text { pancreas, tighter sleeve over-sewing }\end{array}$ & 39 & Staple line reinforcement \\
\hline \multirow[t]{3}{*}{ GER } & $\begin{array}{l}\text { Patients with preoperative history of GER when } \\
<50 \mathrm{~kg} / \mathrm{m}^{2} \mathrm{BMI} \text { offered RYGB }\end{array}$ & 40 & $\begin{array}{l}\text { Preoperative preparation program } \\
\text { supervision }\end{array}$ \\
\hline & Application calibration tube $38 \mathrm{~F}$ & 41 & Operative equipment selection \\
\hline & No over-sewing if not necessary & 42 & Reinforcement of staple line \\
\hline \multirow[t]{2}{*}{ Stenosis } & Application calibration tube $38 \mathrm{~F}$ & 41 & Operative equipment selection \\
\hline & No over-sewing if not necessary & 42 & Staple line reinforcement \\
\hline Trocar site hernia & $\begin{array}{l}\text { Closing the defects post } 12 \mathrm{~mm} \text { trocars with } \\
\text { surgical awl }\end{array}$ & 43 & Operative equipment selection \\
\hline \multirow[t]{2}{*}{ Vomiting } & Application of calibration tube $38 \mathrm{~F}$ & 41 & Operative equipment selection \\
\hline & Following dietary instructions & 45 & Postoperative care \\
\hline \multirow[t]{2}{*}{$\begin{array}{l}\text { Pulmonary embolism, deep } \\
\text { venous thrombosis }\end{array}$} & $\begin{array}{l}\text { Prolonged dalteparin sodium administration } \\
1 \times 5000 \text { IU (4 weeks) }\end{array}$ & 46 & Postoperative care \\
\hline & Fast patient mobilization (6 h post operation) & 47 & \\
\hline
\end{tabular}

diately sutured manually with a negative methylene blue test result. This fact was reported to the stapler producer representative and the firm examined this event as its own production process nonconformity and managed according to its own quality management system.
In one patient both bleeding from the divided gastro-splenic ligament and a slight leak at the site of cartridge connection required additional efforts. The source of bleeding was localized and supplied by LigaSure. The small opening was closed with a single suture. 
There were no conversions to an open procedure. The mean operative time was 122 min (range: 55$180 \mathrm{~min}$ ) in group G1 and 71 min (range: $45-125 \mathrm{~min}$ ) in G2. The average blood loss was significantly reduced from 208 (10-990) $\mathrm{ml}$ in group G1 to 64 (10100) $\mathrm{ml}$ in $\mathrm{G} 2$.

The mean hospital stay was shortened from 6.5 days in group G1 to 3.2 in G2.

All patients reported for established follow-up visits up to 1 year after the procedure. Eleven percent of all 125 individuals ( 6 in G1, 8 in G2) who underwent LSG complained of vomiting episodes shortly after the operation, mainly because of dietary mistakes. In one case from the G1 group the reason was sleeve stricture.

Gastro-esophageal reflux symptoms were observed significantly more often in the G1 group and they corresponded to the diameter of the sleeve. Nine patients (36\%) reported typical GER symptoms and required proton pump inhibitors, while GER in the G2 group was clinically diagnosed in $20 \%$ of cases.

The PA addressed to the potential adverse events have been detailed as process recommendations in Table IV and Figure 1.

\section{Discussion}

Laparoscopic sleeve gastrectomy is gaining popularity among obese patients and bariatric surgeons. The attractiveness of this procedure from operators' perspective results from the seemingly undemanding technique. No anastomoses, fully stapled course of stomach resection, laparoscopic approach and unsophisticated surgical equipment requirements influence the relatively short 'learning curve' which has been defined for 30 cases while for LRYGB is established for even 100 operations [8]. Thus, the exceptional feasibility and the high demand for this well-tolerated, minimally invasive method tempt even less experienced bariatric surgeons to perform it more widely.

Nevertheless, the high pressure sleeve created with a long staple margin line, preceded by intensive division of fat-rich ligaments, seems to be conducive to increased risk of complications [19]. Even in high volume centers [15, 20-22], the rate of bleeding and leaks, which are considered as the main complications of LSG, impairs the safety of the bariatric service. Weiner et al. [3] reported more frequent occurrence of leaks after LSG than RYGB.

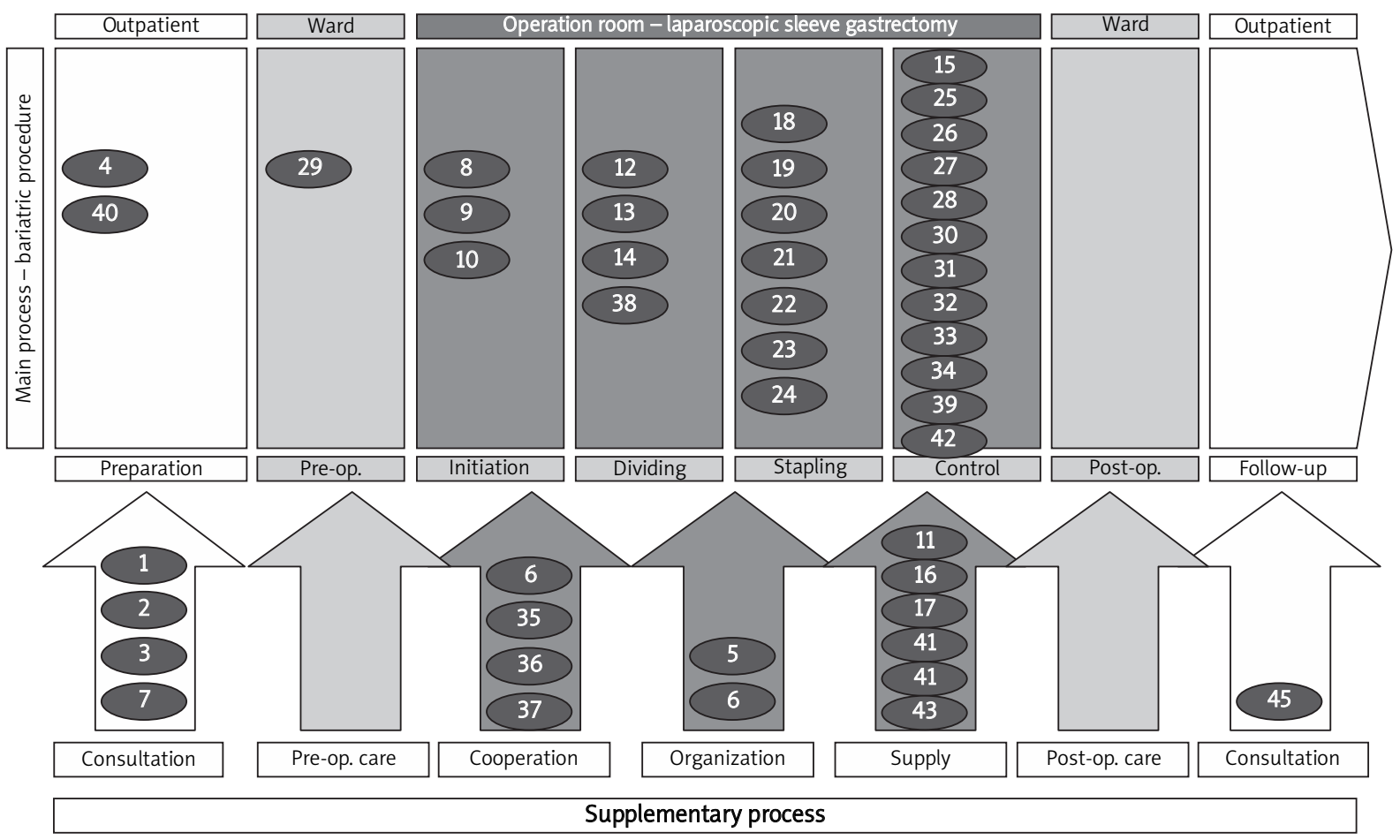

Figure 1. Map of the LSG process 
However, in our center, where the prevailing bariatric procedure is gastric bypass, we have not observed leaks in our LSG material. Intra- and postoperative bleeding was the dominant complication of sleeve gastrectomy. The risk of bleeding from the staple line can be managed with routine margin line reinforcement or using cartridges enriched in various hemostatic membranes [16]. The most convenient cartridge membranes multiply the total cost of the procedure and have not been accepted in our center also because of their non-confirmed influence on the potential leaks [16]. The over-sewing of the staple line has been described as a simple and sufficient maneuver but it does not unequivocally protect from leakage $[3,15]$.

Although a well-known, quite simple, very effective and cheap technique should be readily considered as the standard, it has not been implemented as a routine part of the procedure, not only in our center $[15,16]$.

To obtain the answer for that issue, a deeper analysis of the root cause of the problem was necessary. Neither the delicate surgical technique required, nor the unavailable laparoscopic instruments, but the time-consuming part of the almost finished operation, especially in the late afternoon period, was identified by our team as the true reason why this intraoperative preventive action was abandoned in most of the cases.

The change in organizing the bariatric service by scheduling the LSGs in one day in a designated operating room, enrolling an experienced team, was recognized as the key modification of the LSG process resulting in the series of 100 uncomplicated procedures. The important role of organizing the OR functioning and its influence on bariatric patients' outcomes has been emphasized by Stepaniak et al. [23].

To encourage the operators additionally to secure the staple line, the unidirectional thread has been offered. This convenient device that eliminates the need for tying knots has been enthusiastically applied especially in G2 patients, with thin, proportionally to the staple height, stomach wall.

As has been reported previously by others $[3,16$, $18,24]$ and is observed in our own material, the reinforcement of the staple line can increase the rigidity of the created reservoir and can lead to higher frequency of gastroesophageal reflux disease (GERD) symptoms. Therefore the authors did not establish over-sewing as a mandatory injunction.
Moreover, our unpublished experimental study of tensile strength of resected stomach staple line demonstrated that leaks appeared in the places of cartridge joints at similar pressure $\left(60-80 \mathrm{~cm} \mathrm{H}_{2} \mathrm{O}\right)$ regardless of the presence and sort of reinforcement. The contrast outflow has been registered proportionally sooner when the angle between the sections of staples was acute. This phenomenon corresponds with the acknowledged recommendation to apply the staplers along the calibration tube in one line [16].

Bleeding from the fragile vessels, shrouded in surrounding fat, is specified as one of the frequent postoperative complications [15]. While the authors appreciate the value of the harmonic scalpel in laparoscopic procedures where the anastomoses are performed, the vessel sealing device gains an advantage over other advanced hemostatic tools in dividing thick gastric ligaments, through the size of its clamps.

Another innovation in the preoperative part of the process improved the LSG outcome. The more intensive preoperative patient preparation leading to loss of $10-15 \%$ body weight and ultra-low carbohydrate diet inducing liver downsizing [16] provided better exposure of the operating field and helped to avoid futile operations.

The 'functional' narrowing of too tight sleeve was observed in place of the angular incision of the stomach in several cases during contrast radiography. The extra tightened, by continuous suture of the resection margin, gastric tube intensified this trend. Postoperative reflux symptoms were significantly more frequently noticed in the G1 group where a thinner bougie was used for calibration. It has also been reported by other researchers $[25,26]$. Thus, utilization of a $38 \mathrm{~F}$ calibration tube instead of $30 \mathrm{~F}$ could prevent sleeve stricture, particularly in sole intended LSG with longer greater curvature resection. In group G2, stenosis was not detected after LSG.

Instances of GERD were significantly rare in comparison with patients from the G1 group. The higher than $40 \mathrm{~F}$ fashioned sleeves, though suggested by other authors [16] as the optimal, manifest a trend to non-functional distention of the gastric tubes a few years after LSG and lead to weight regain [3, 25, 27].

Another complication that has been managed in this study, pancreatitis, is not commonly observed [15]. Investigating this adverse incident, the authors identified, as the most possible reason, activation of the harmonic scalpel too close to the pancreatic surface, while liberating the posterior stomach wall from 
the adhesions. To minimize the risk of pancreatic irritation, it has been recommended to prefer tighter over-sewing of the tube to achieve an adequate volume, than intensive and deep division of the adhesions in pancreas contiguity. Hyperamylasemia was never detected postoperatively in the subsequent 100 LSG.

It has been underlined in this study that systemic complications management influenced the outcome after subsequent LSGs. Concepts inspired by quality mechanisms successfully implemented in industry, based on the ISO 9001 norm, can guarantee continuous quality improvement also in medical service [28]. It was recognized as the most crucial effect of the learning curve, more important than only manual operative training.

The monitoring of intra-operatively treated complications which do not influence the short- and long-term postoperative course is not generally practiced [15] but could be a source of inspiration improving the overall proficiency of the process. In our routine practice, classifying intra-operative difficulties as nonconformities sharpened the criteria of defining what is adverse in the procedure. The risk analysis should be the core component in designing the process.

Several preventive actions like those demonstrated in the study and detailed in Table IV significantly reduced the number of unwanted events in our material of LSG.

\section{Conclusions}

The systemic approach to the bariatric procedure by innovating the entire process can significantly reduce the rate of complications and adverse events. The 'learning curve' should not be limited only to the manual operative training but also extend to each part of the procedure. Preventive actions based on risk analysis should be considered as the core component in redesigning the process.

\section{References}

1. Gumbs A, Gagner M, Dakin G, et al. Sleeve gastrectomy for morbid obesity. Obes Surg 2007; 17: 722-7.

2. Akkary E. Bariatric surgery evolution from the malabsorbtive to the hormonal era. Obes Surg 2012; 22: 827-31.

3. Weiner RA, Theodoridou S, Weiner S. Failure of laparoscopic sleeve gastrectomy - further procedure? Obes Facts 2011; 4 (Suppl 1): 42-6.

4. Rao RS, Kini S. Diabetic and bariatric surgery: a review of the recent trends. Surg Endosc 2012; 26: 893-903.
5. Buchwald H, Avidor $\mathrm{Y}$, Braunwald E, et al. Bariatric surgery: a systemic review and metaanalysis. JAMA 2004; 292: 1724-37.

6. Chu CA, Gagner M, Quinn T, et al. Two stage laparoscopic BPDDS: an alternative approach to super-super morbid obesity. Surg Endosc 2002; 16: S069.

7. Regan JP, Inabnet WB, Gagner M, Pomp A. Early experience with two stage $L R Y G B$ as an alternative in super-super obese patients. Obes Surg 2003; 13: 861-4.

8. Clinical Issues Committee of American Society for Metabolic and Bariatric Surgery (2007). Sleeve gastrectomy as a bariatric procedure. Surg Obes Relat Dis 2007; 3: 573-6.

9. Milone L, Strong V, Gagner M. Laparoscopic sleeve gastrectomy is superior to endoscopic intragastric balloon as a first stage procedure for super obese patients $(\mathrm{BMI}>\mathrm{Or}=50)$. Obes Surg 2005; 15: 612-7.

10. Silecchia G, Boru C, Pecchia A, et al. Effectiveness of laparoscopic sleeve gastrectomy (first stage of BPD with DS) on comorbidities in super-obese high-risk patients. Obes Surg 2006; 16: 1183-44.

11. Brathauer SA, Hammel JP, Schauer PR. Systematic review of sleeve gastrectomy as the staging and primary bariatric procedure. Surg Obes Relat Dis 2009; 5: 469-75.

12. Karamanakos SN, Vagenas K, Kalfarentzos F. Weight loss, appetite suppression, and changes in fasting and postprandial ghrelin and peptide-YY levels after Roux-en-Y gastric bypass and sleeve gastrectomy: a prospective, double blind study. Ann Surg 2008; 247: 401-7.

13. Hady Razak H, Dadan J, Gołaszewski K, et al. Impact of laparoscopic sleeve gastrectomy on BMI, ghrelin, insulin and lipid levels in 100 obese patients. Videosurgery Miniinv 2012; 7: 251-9.

14. Kehagias I, Karamanakos SN, Argentou M, et al. Randomized clinical trial of laparoscopic RouX-en-Y gastric bypass versus laparoscopic sleeve gastrectomy for the management of patients with $\mathrm{BMI}<50 \mathrm{~kg} / \mathrm{m}^{2}$. Obes Surg 2011; 21: 212-6.

15. Lalor PF, Tucker ON, Szomstein S, et al. Complications after laparoscopic sleeve gastrectomy. Surg Obes Relat Dis 2008; 4: 33-8.

16. Rubin M, Tzioni R, Stein M, et al. Laparoscopic sleeve gastrectomy with minimal morbidity. Early results in 120 morbidly obese patients. Obes Surg 2008; 18: 1567-70.

17. www.ifso.com

18. ISO 9001:2008 Quality management systems - Requirements www.iso.org

19. Szewczyk T, Janczak P, Duszewski M, et al. Technical problems in laparoscopic sleeve gastrectomy. Videosurgery Miniinv 2009; 4: 95-101.

20. Lee CM, Cirangle PT, Jossart GH. Vertical gastrectomy for morbid obesity in 216 patients: report of two-year results. Surg Endosc 2007; 21: 1810-6.

21. Van Rutte PWJ, Smulders JF, de Zoete JP, Nienhuijs SW. Indications and short term outcomes of revisional surgery after failed or complicated sleeve gastrectomy. Obes Surg 2012; 10: 1903-8.

22. Paluszkiewicz R, Kalinowski P, Wróblewski T, et al. Prospective randomized clinical trial of laparoscopic sleeve gastrectomy versus open Roux-en-Y gastric bypass for the management of patients with morbid obesity. Videosurgery Miniinv 2012; 7: 225-32. 
23. Stepaniak PS, Heij C, Buise MP, et al. Bariatric surgery with operating room that stayed fixed during the day: a multicenter study analyzing the effects on patient outcomes, teamwork and safety climate and procedure duration. Anesth Analg 2012; 115: 1384-92.

24. Mukherjee S, Devalia K, Rahman MG, Mannur KR. Sleeve gastrectomy as a bridge to a second bariatric procedure in superobese patients - a single institution experience. Surg Obes Relat Dis 2012; 8: 140-4.

25. Weiner RA, Weiner S, Pomhoff I, et al. Laparoscopic sleeve gastrectomy -influence of sleeve size and resected gastric volume. Obes Surg 2007; 17: 1297-305.

26. Yehoshua RT, Eidelman LA, Stein M, et al. Laparoscopic sleeve gastrectomy - volume and pressure assessment. Obes Surg 2008; 18: 1083-8.

27. Langer FB, Bohdjalian A, Felberbauer FX, et al. Does gastric dilatation limit the success of sleeve gastrectomy as a sole operation for morbid obesity? Obes Surg 2006; 16: 166-71.

28. Scott DJ ISO 9001 and hospital accreditation - putting a man on the Moon. www.dnvaccreditation.com

Received: 18.01.2013, accepted: 14.03.2013. 